\title{
제928차 $\mathrm{OECD/DAC} \mathrm{정례회의}$
}

\section{I. 회의개요}

표제 회의가 2011.3.15 파리 $\mathrm{OECD}$ 본부에서 $\mathrm{OECD}$ 사무국(개발협력국)주관으로 개최되어 Brian Atwood DAC의장, 각 회원국 DAC대표, DAC 비회원국 $\mathrm{OECD}$ 회원국 대표, 중국, 브라질, 남아공, 인도네시아 등의 관계강화국 대표, 세계은행 그리고 $\mathrm{IMF}$ 등이 참석한 가운데 개최되었음.

\section{II. 주요내용}

- 오는 4.6 7 파리에서 개최 예정인 DAC고위관리회의(SLM) 진행방식(stage management)과 의제 논의. 특히 부산세계개발원조총회(HLF-4)에 제시할 DAC차원의 정치적 메시지를 어떻게 도출할 것인지를 중점 협의함.

- Atwood 의장은 지난 주 원조효과작업반 집행위에서 DAC의장명의로 발표한 부산 $\mathrm{HLF}-4$ 의 정치 적 맥락 5 가지 포인트에 대해 설명하고, 금년 하반기 부산총회는 원조냐 개발이냐에 관한 프레임 워크 전환 논의를 넘어 양자를 모두 포괄하는 보다 큰 패러다임을 국제사회에 제시하는 회의가 되 어야 한다는 점을 강조

- 참석자들은 금번 SLM의 핵심의제가 부산 $\mathrm{HLF}-4$ 에 대한 정치적 메시지 도출이라는데 공감을 표 시하면서, 현재의 어젠다를 부산 $\mathrm{HLF}-4$ 의 일정에 맞춰 재편성해 줄 것을 요청

- DAC의장은 부산총회를 준비하는 주체는 원조효과작업반이지만, 부산 총회에 대한 공여국의 입장 을 제시하는 핵심포럼은 $\mathrm{DAC}$ 라고 언급하면서, 양 포럼 모두 회원국 정부의 의견이 제시된다는 측 면에서 공통점을 가지지만, DAC은 공여국의 집단적 정치적 의지의 표명(collective political willl of donors)이라는 차별성을 갖는다는 점을 강조

- 의장은 3.15 현재 이미 많은 회원국이 4월 SLM에 대외원조청 부청장급 또는 총국장급 고위대표단 파견의사를 전달해 왔음을 언급하면서, 금번 SLM은 DAC회원국, OECD 회원국 중 DAC비회원국, 관계강화 5 개국, 세계은행, IMF, UNDP 등 국제기구 고위 대표, 원조효과작업반 공동의장(2인) 등 이 참석하게 될 것이라고 설명함.

- 위원회는 보다 실질적인 SLM의제 논의 준비를 위해 3 월말 DAC 비공식회의를 개최키로 합의하였 으며, 사무국은 동 회의시 주요 정치적 논의 의제들의 토의방향에 대해 보다 명확한 회원국들의 입 장 제시를 요청 